\title{
'CERRÁSTEME LA PUERTA RIGUROSA': EXCLUSUS AMATOR, UN TÓPICO CLÁSICO EN LAS LETRAS ESPAÑOLAS
}

\author{
ANTONIO RAMAJO CAÑO \\ Universidad de Salamanca
}

\section{1. «AT LACRIMANS EXCLUSUS AMATOR...»: LA ANTIGÜEDAD GRECOLATINA ${ }^{1}$}

El término de exclusus amator o, en griego, paraclausíthyron ${ }^{2}$, nombra, en esencia, el lamento proferido por el amante rechazado, a la puerta de la amada, o, incluso, simplemente, la guardia que éste prolonga ante los batientes cerrados ${ }^{3}$. Pretendemos nosotros en nuestro estudio dejar unas muestras, sin ánimo de exhaustividad, de este tópico en las letras hispanas. Nos mueve más un urgente afán de inventario, aunque sea incompleto, que de análisis de los textos singulares. Ofrecemos, a manera de introducción, de forma sintética, unas ejemplos en la literatura grecolatina, que

\footnotetext{
${ }^{1}$ Lucrecio ofrece un interesante texto por cuanto en él aparece el sintagma que da nombre al tópico. Lo que el autor pretende no es cantar el tema, sino tratar de ayudar a liberarse de la pasión a los enamorados. Lucrecio, en tono de poeta satírico, repara en los defectos de las amadas ignorados por el ciego amante, que sufre a la puerta: «At lacrimans exclusus amator limina saepe / floribus et sertis operit postisque superbos/ unguit amaricino et floribus miser oscula figit» (De rerum natura, IV, 1177-1179: 'Y el amante, cerrada la puerta, empapado de lágrimas, cubre una y otra vez el umbral de flores y guirnaldas, unge de perfume las puertas desdeñosas, y llena de besos, en su desgracia, sus batientes' ). Cf. una expresión de la misma familia en una elegía de Ovidio a la que luego nos referiremos: el amante se dirige a un portero: «Quid facies hosti, qui sic excludis amantem?» (Amores, I, vi, 31: ¿Qué harás a un enemigo, tú que expulsas a un amante?').

${ }^{2}$ Este término figura en Plutarco, Amatorius, 753b (vid. Copley, 1956, p. 144).

${ }^{3}$ Nos basamos en la definición que proporciona Copley, 1956, p. 1, aunque sin ser fieles deudores de ella: "The paraclausithyron is the song sung by the lover at his mistress's door, after he has refused admission to her house». Y es que no siempre se manifiesta explícito el lamento del enamorado (vid. Ekklesiazusai, 938-375, de Aristófanes, que luego tornaremos a citar). Es importante también para el estudio del tópico Henderson, 1973. Cf, para un lugar concreto en la reelaboración del mismo, Schmeling, 1969.
}

Rlit, LXVI, 132 (2004), 321-348 
proporcionen perspectiva histórica a las posteriores observaciones. Añadiremos otros textos de la literatura neolatina, para entrar, por fin, en el campo propio del presente estudio.

Ya en la lírica arcaica griega encontramos un poemita de Alceo en que el hombre, en noche disipada, suplica acogida:

$$
\begin{aligned}
& \text { «Ábreme la puerta, } \\
& \text { que ando de jarana!; } \\
& \text { ¡abre, te lo ruego!» }{ }^{4} \text {. }
\end{aligned}
$$

La Antología Palatina ${ }^{5}$ es cauce óptimo para la recogida de los diversos tópicos y fórmulas literarios. El libro $\mathrm{V}$, dedicado a la poesía amorosa, se enriquece con una cosecha notable del tema estudiado. En los diversos poemas se agrupan los elementos diferenciadores del exclusus amator, como la súplica del amante, la noche fría, la obstinación de la muchacha o las guirnaldas con que el enamorado orna la puerta. Entre los autores destaca el gran Calímaco, del que traducimos el epigrama en que reelabora el motivo:

«iOjalá duermas tú así, Conopion, como a mí me haces pasar la noche bajo estos fríos pórticos! ¡Ojalá duermas tú así, perfidísima, como haces dormir al amante! $\mathrm{Ni}$ en sueños me has tenido piedad. Los vecinos sí se compadecen; tú, ni en sueños. Cuando el cabello canee, te acordarás de esto» (Antología Palatina, V, 23) ${ }^{6}$.

Otros dos poetas, en esa colección y en ese libro, dejarán su aportación: Asclepiades ${ }^{7}$ y Meleagro. Este último reelabora de forma original el

${ }^{4}$ Es la traducción de Ferraté, 1968, p. 295. Cf. ya Ramajo, 2000, p. 332. Para el culto que al vino rinde una y otra vez Alceo, cf. Ortega, 1974, pp. 104-109.

${ }^{5}$ La Antología Palatina (o mejor: Antología Griega) es, en realidad, una magna colección (dieciséis libros) de florilegios recogidos o reelaborados en un largo periodo: desde el s. I a. C. hasta el XIII d. C. Pero los poemas en ella contenidos dilatan aún más el tiempo, pues figuran epigramas de la Grecia arcaica. El nombre le viene del códice Palatinus Graecus de la Biblioteca Universitaria de Heildelberg (para las vicisitudes textuales, cf. Antología Palatina, vol. I, pp. XXI-XLIX). Se señalará oportunamente la edición de la que se toman las traducciones del presente estudio, salvo cuando incorporemos una versión personal, caso en el que no haremos ninguna indicación.

${ }^{6}$ Calímaco introduce al final de su epigrama un nuevo tema de la poesía amorosa: cuando llegue la vejez, la esquiva amada se acordará, en vano, de tiempos en que pudo dar su amor: cf. Ramajo, 2000, p. 332.

${ }^{7}$ Para Asclepiades (s. III a. C.), cf. V, 145, en que el lamento se profiere por un muchacho: «Quedaos ahí, mis guirnaldas, sobre la puerta colgadas, / sin prisa por sacudir los pétalos, que mi llanto / empapó - ¡lluviosos son los ojos de los amantes! - / Y cuando abrir la puerta lo veáis, sobre su cabeza / gotead esa lluvia de mi llanto para que mis lágrimas, / al menos, mejor beba su rubia cabellera» (trad. de C. Rodríguez y Marta González 1999, p. 82). Cf. del mismo autor, V, 164: «iOh, noche, a ti y no a otra por testigo pongo de cuán mal / me trata la hija de Nico, Pitíade, amiga de enga- 
tópico: despechado el poeta, pone coronas en la puerta de la amada como exvotos que indican la despedida de tan infausto amor (Antología Palatina, $\mathrm{V}, 191)$.

La poesía bucólica acoge bien temas relacionados con la poesía amatoria. Nada tiene de particular que Teócrito se sirva del paraclausíthyron en su idilio VII: el pastor Simíquidas, en su canto aconseja a su amigo Arato que olvide su amor por Filino:

«Cesemos ya, Arato, de velar a su puerta y de cansar los pies. Que el gallo a la alborada con su canto deje en otro torpor y desaliento...» ${ }^{8}$.

Pero el tópico no aparece sólo en lo que cabría calificar de poesía lírica. Aristófanes lo presenta en Ekklesiazusai, 938-975, y Plauto en Curculio, 145-155, bien es verdad que dentro de la necesidad que impone el texto teatral. En ambos casos, el amante, en. la noche de ronda, tras la súplica, no es rechazado, pues la puerta se abre, al fin. El tópico no ofrece, en consecuencia, el desenlace habitual ${ }^{9}$. En todo caso, la inserción del tema en un texto teatral resulta interesante para nuestro estudio, por cuanto veremos que también Lope de Vega, en sus comedias, sabe intercalar la plegaria desesperada del enamorado. Por otro lado, la reelaboración plautina aporta la interpelación del enamorado dirigida a la propia puerta, frecuente en otras piezas literarias:

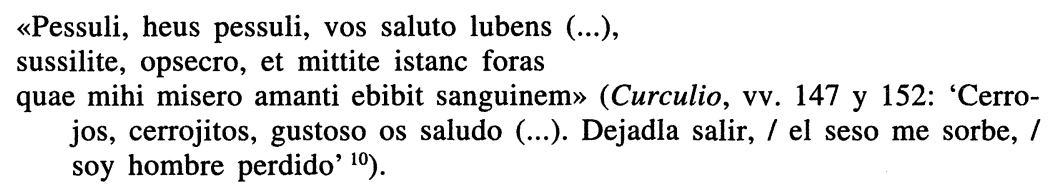

En la literatura latina puede recogerse abundante cosecha del tópico ${ }^{11}$. Horacio dedica una famosa oda (III, $\mathrm{x}$ ) al tema, que reproduciremos por cuanto ha dejado buena huella en la literatura española, según veremos posteriormente:

ños. / Invitado vine, llamado por ella. ¡La misma suerte sufra / y a mi puerta quejas te dirija por afrenta igual!» (trad. de C. Rodríguez y Marta González, 1999, p. 86); cf. n. ${ }^{\circ}$ 167: como en el epigrama anterior, como en el citado de Calímaco, se desea al objeto del amor el mismo destino que el enamorado está sufriendo; y cf. 189: «La noche es larga; es el invierno (...). Y yo, delante de su puerta, me paseo empapado de lluvia» (siempre que no se haga observación en contrario, las traducciones son nuestras).

${ }^{8}$ Cf. la traducción de Bucólicos griegos, p. 107. También puede considerarse que existe tratamiento del tema en el idilio III: a partir del v. 6, hasta el final, un cabrero corteja a Amarilis, que se niega a salir de su gruta.

${ }^{9}$ Cf. Copley, 1956, pp. 9-10. Idéntico procedimiento se comprueba en Terencio, El eunuco, vv. 46-49.

10 Vid. la traducción de González-Haba, 1996, p. 67. 
«Extremum Tanain si biberes, Lyce, saevo nupta viro, me tamen asperas porrectum ante foris obicere incolis plorares Aquilonibus.

Audis quo strepitu ianua, quo nemus inter pulchra satum tecta remugiat ventis, et positas ut glaciet nives puro numine Iuppiter?

Ingratam Veneri pone superbiam, ne currente retro funis eat rota: non te Penelopen difficilem procis Tyrrhenus genuit parens.

$\mathrm{O}$ quamvis neque te munera nec preces nec tinctus viola pallor amantium nec vir Pieria paelice saucius curvat, supplicibus tuis

parcas, nec rigida mollior aesculo nec Mauris animum mitior anguibus: non hoc semper erit liminis aut aquae caelestis patiens latus».

('Aunque del remoto Tanais bebieras las aguas, Lice, con áspero varón casada, tendrías que dolerte de verme tendido a la intemperie de los Aquilones, dueños del país.

¿Oyes el estrépito de la puerta, el resonar del bosque plantado en medio de tu bella casa, al mugir el viento? ¿Ves cómo se hielan las nieves caídas por obra del sereno numen de Júpiter?

Quítate ese orgullo que a Venus desagrada; teme que cable y rueda corran hacia atrás; que no te engendró Penélope esquiva para los pretendientes un padre tirreno.

Aunque no te ablanden los regalos, las súplicas, la palidez de tus amantes, en viola convertidos ${ }^{12}$, el que a tu marido hiera de amor una amiga pieria, ten piedad de los suplicantes,

tú, no más blanda que la dura encina, no más dulce que serpientes moras. Mira que este costado no siempre aguantará tus umbrales ni las aguas del cielo') ${ }^{13}$.

${ }^{11}$ Existen textos en que no cabe hablar de Exclusus amator, aunque el autor tome algún elemento del tópico: así, en Catulo, 67, si bien el poeta habla con la puerta, no se presenta a ningún amante rechazado; el poema constituye una diffamatio, sobre el comportamiento inmoral de la dueña de la casa.

${ }^{12}$ Adaptamos aquí la expresión de Garcilaso, canción V, 28: «convertido en vïola».

${ }^{13}$ Cf. el análisis detenido que del poema presenta Copley, 1956, pp. 62-64. El tema del Exclusus amator aparece con cierta frecuencia en Horacio (Henderson, 1973, p. 54). Vid. Odas, I, 25: La vieja Lidia ya duerme tranquila. La vejez hace que no soliciten su puerta los jóvenes. Villeneuve, 1970, p. 37, nota 2, remite a Anacreonte: «Duerme él tranquilo, sin tener que echarle el cerrojo a la puerta de la casa» (Líricos griegos arcaicos, p. 335; cf., además, Cristóbal, 1990, p. 142). Vid. III, 7 («Quid fles, Asterie, quem tibi candidi...»), de una manera alusiva en los cuatro últimos versos, en los que el poeta invita a Asteria a ser fiel a su marido ausente: «prima nocte domum claude neque in 
En los poetas elegíacos latinos, el tema del Exclusus amator surge con alguna frecuencia. Ello resulta comprensible, no sólo porque se adapta al universo semántico de las composiciones de tales creadores, sino también por el conocimiento que éstos atesoran de la cultura griega. Así, Tibulo, I, ii ${ }^{14}$, ofrece una personificación de la puerta. El amante soporta la inclemencia de la noche. Imposible resulta acceder a la bien custodiada amada. En su desesperación, el enamorado llega a hablar con esas maderas inexorables de forma un tanto contradictoria:

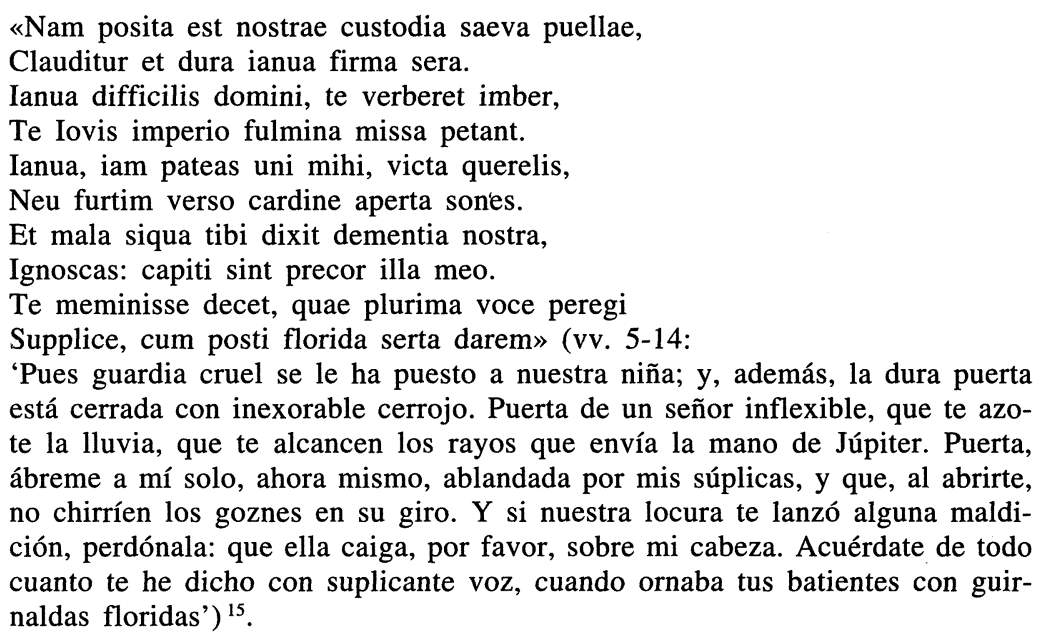
está cerrada con inexorable cerrojo. Puerta de un señor inflexible, que te azote la lluvia, que te alcancen los rayos que envía la mano de Júpiter. Puerta, ábreme a mí solo, ahora mismo, ablandada por mis súplicas, y que, al abrirte, no chirríen los goznes en su giro. Y si nuestra locura te lanzó alguna maldición, perdónala: que ella caiga, por favor, sobre mi cabeza. Acuérdate de todo cuanto te he dicho con suplicante voz, cuando ornaba tus batientes con guirnaldas floridas') ${ }^{15}$.

Interesa en Propercio la elegía I, xvi, pues en ella se encuentra la prosopopeya de la puerta, que se queja de ser golpeada por la noche y del desorden nocturno de los transeúntes. Pero, además, el enamorado le dirige sus reproches: «Ianua vel domina penitus crudelior ipsa, / quid mihi tan duris clausa taces foribus?» (vv. 17-18: 'Puerta mucho más cruel que la propia dueña, ¿por qué para mí guardas silencio, cerrada con inexorables batientes?') ${ }^{16}$.

vias / sub cantu querulae despice tibiae/ et te saepe vocanti / duram difficilis mane» (vv. 29-32). Véase, además, Odas, III, 9: dos amantes se reconcilian: Lidia volverá a entrar en casa del amado: «reiectaeque patet ianua Lydiae» (v. 20) —es de señalar la nota original de que la rechazada ante la puerta es la mujer-. Cf. también Odas, III, 15: la hija de Cloris, joven, busca el amor: «Filia rectius / expugnat iuvenum domos» (vv. 8-9): única posible alusión al tema que nos ocupa. Véase también III, 26 (v. 8). Cf. Sátiras, I, ii, 64-67; II, iii, 259-275 (cf. Alvar, 1994, p. 136); Epodos, XI, 20-22 (cf. Alvar, 1994, p. 135).

${ }_{14}$ Para la cultura helénica de Tibulo, cf. Luck, 1992, pp. 87-101.

${ }_{15}$ Véase una alusión al tema en Tibulo, I, viii, 76.

${ }^{16}$ Cf. el excelente comentario de Fedeli, 1980, pp. 363-399. Propercio, en sus Elegías, I, iii, se hace eco del poema citado de Calímaco (Antología Palatina, V, 23) 
Ovidio se sirve frecuentemente del tópico en Amores ${ }^{17}$. Destaca I, vi, pues el motivo abraza todo el poema. El poeta suplica en vano al portero («Ianitor», v. 1) que le franquee la puerta. A intervalos se repite un verso que desempeña el oficio de estribillo: «Tempora noctis eunt; excute poste seram» (vv. 24, 32, 40, 48, 56: 'Se van las horas de la noche; descuelga la barra de la puerta'). El poema concluye con una invocación al gran obstáculo que le aparta de la amada: «Vos quoque, crudeles rigido cum limine postes / duraque conservae ligna, valete, fores» (Amores, I, vi, 73-74: 'Adiós también vosotras, puertas crueles de umbral inexorable, duras maderas, batientes compañeras de esclavitud' ${ }^{18}$ ).

-cf. Fedeli, 1980 , p. 132-, dentro de su contexto particular de las conflictivas relaciones con Cintia. El poeta llega a casa de la amada, que le reprocha el que venga de intentar otra cita, en la que ha padecido los rigores propios del exclusus amator: «Tandem te nostro referens iniuria lecto / alterius clausis expulit a foribus? / Namque ubi longa meae consumpsti tempora noctis, / languidus exactis, ei mihi, sideribus? / O utinam talis perducas, improbe, noctes, / me miseram qualis semper habere iubes!» (vv. 35-40: ‘ ¿Al fin, el desdén de otra te trajo a nuestro lecho, al rechazarte de sus puertas cerradas? ¿Dónde has pasado el tiempo de mi noche, impotente, ¡ay de mí! - las estrellas ya cumplieron su curso-?'). Para otras ligeras alusiones en Propercio al tema estudiado, vid. II, vi, 2, y II, xxiii, 12.

${ }^{17}$ Cf., además del poema reseñado en el cuerpo del texto, I, iv, 61-62: el amante arde por una casada. La noche supondrá la separación de la pareja: «Nocte vir includet; lacrimis ego maestus obortis, / qua licet, ad saevas prosequar usque fores» ('De noche la encerrará el marido; y yo, afligido, entre sollozos la seguiré mientras pueda, hasta la puerta cruel'). Cf. I, viii: la vieja Dipsas, antecesora de nuestra Celestina, amonesta a una joven para que saque ganancia de sus relaciones. El amor hay que pagarlo, viene a decirle: «Surda sit oranti tua ianua, laxa ferenti» (v. 77: 'Que tu puerta sea sorda al que suplica, blanda, al que regala'). Vid. I, ix: se trata de la famosa elegía que comienza «Militat omnis amans et habet sua castra Cupido» ('Todo amante es soldado, y Cupido tiene sus propios campamentos'). El poeta establece, según ve, equiparación entre soldado y amante (es el tipico de la militia amoris): «Ille fores dominae servat, at ille ducis» (v. 8: 'El uno guarda la puerta de su señora; el otro, la de su jefe' ); «Ille graves urbes, hic durae limen amicae / obsidet; hic portas frangit, ut ille fores» (vv. 19-30: 'Aquél asedia fuertes ciudades; éste, el umbral de su amiga, inflexible; éste quebranta las puertas de una casa, como aquél las de una ciudad' ). Cf. II, i: este poema liminar constituye una recusatio: el poeta pretendía haber cantado temas elevados, como la Gigantomaquia, pero el amor es más fuerte: volverá a retomarlo en sus versos, y resurgirá el tema de la puerta cerrada (v. 17). Pero aquí se ofrece una novedad: los versos del poeta tienen tal fuerza que hasta las puertas se ablandan: «Mollierunt duras lenia verba fores» (v. 22: 'Suaves palabras dulcificaron inflexibles puertas': cf. la misma idea en los vv. 27-28). Vid. II, xix: el poeta siente que la pasión se le acrecienta cuando la amada se muestra esquiva: por eso conviene que el amante sufra: «Et sine me ante tuos proiectum in limine postis / longa pruinosa frigora nocte pati» (vv. 21-22: 'Deja que, tendido en los umbrales, ante tu puerta, sufra, la noche entera, el frío del relente'). Cf., todavía, para una alusión al tema, Amores, III, viii, 24.

${ }^{18}$ Las puertas son 'compañeras de esclavitud' del esclavo guardián, Ianitor, con quien el poeta había estado hablando a lo largo del poema. 


\section{2. «ANTE TUAS... FORES EGO SEMPER OBERRO...»: LA POESÍA NEOLATINA}

Se hace necesario investigar la posible aparición del tópico en la poesía neolatina. Dejamos aquí unas escasísimas muestras ${ }^{19}$.

Landino, en «Ad Franciam», Xandra, II, $20^{20}$, ofrece una elegía claramente deudora de Ovidio, Amores, I, vi, antes citado. Tiene la obra, en efecto, el verso que se repite a modo de estribillo: «Surge, seram foribus, Francia, pelle seram» ('Levántate, Francia, y mueve la barra en tu puerta', vv. $8,12,22$ y 28 ). Pero la elegía de Landino, a diferencia de la de Ovidio, concluye bien. «Francia nostra venit!» (v. 44).

Sannazaro toca el tema levemente en Eclogae piscatoriae, III, «Mopso», en una tirada de versos amebeos: Habla Iolas en respuesta al pastor Chromis (es clara la influencia virgiliana ${ }^{21}$ ):

«In fluviis mugil versatur, sargus in herbis, ante tuas, mea Nisa, fores ego semper oberro...» (vv. 90-92) ${ }^{22}$.

3. «VOS, PUERTAS, SOIS TESTIGOS DE MIS MALES»: LAS LETRAS ESPAÑOLAS

Alguna cosecha hemos encontrado nosotros en las letras hispanas ${ }^{23}$. Entramos ya en el corazón de nuestro trabajo.

Acaso Bartolomé de Torres Naharro sea deudor del tópico en este pasaje de su Comedia Ymenea, en que el amador Ymeneo se queja de Phebea:

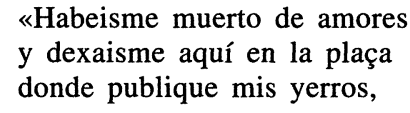

${ }^{19}$ Obviamente también habría que investigar la aparición del tópico en la poesía latina de la Edad Media. Nada encontramos al respecto, y ello es significativo, en el magno corpus, de Szövérffy, 1992-1995. El tópico sí emerge en un poema anónimo latino del siglo XI, pero bajo la configuración del Cantar de los Cantares: «Quis est hic qui pulsat ad ostium, / noctis rumpens somnium? / me vocat: 'o virginum pulcherrima, / soror, coniux, gemina splendidissima!’ (...)» (vv. 1-4, en Raby, 1984, p. 158).

${ }^{20}$ Vid. Musae Reduces, I, pp. 54-56.

${ }^{21}$ Vid. Bucólicas, III, 60 ss.: tirada de versos amebeos, entre Damoetas y Menalcas.

${ }^{22}$ Vid. ed. de Arnaldi y Gualdo, 1976, II, p. 182. Juan Segundo roza el tema en sus Elegiae, I, vii, 74, cuando se imagina la libertad amorosa existente en la mítica Edad de Oro: «Nulla erat invisis clausa domus foribus» ('Odiosas puertas no cerraban casa alguna': cf. Basia et alia quaedam, p. 184).

De la existencia del tópico en la lírica neolatina escrita en España no aporta indicio el trabajo de Alcina, 1979.

${ }^{23}$ No nos enseña nada de provecho para nuestro objetivo el trabajo de Rosenstein, 1998. Algunas muestras del tópico pueden verse en Ramajo, 1993 y 2000 . No entramos a dilucidar el posible valor erótico de puerta (cf. Pedrosa 2002). 


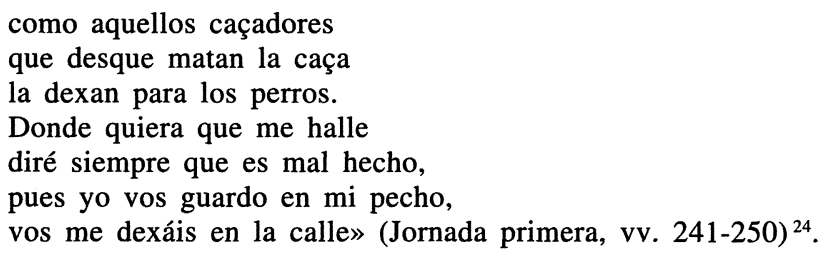

Pero el sufrimiento de Ymeneo es pasajero, por cuanto a la postre Phebea, apiadada, le abrirá la puerta, y todo concluirá en la dicha del matrimonio.

Diego Hurtado de Mendoza narra en una «Carta» la historia de Anaxárate e Ifis, para expresar la extraordinaria dureza de su dama, a manera de exemplum mitológico. El joven Ifis rondará sin fruto la casa de la amada. El tópico brota con gran pureza:

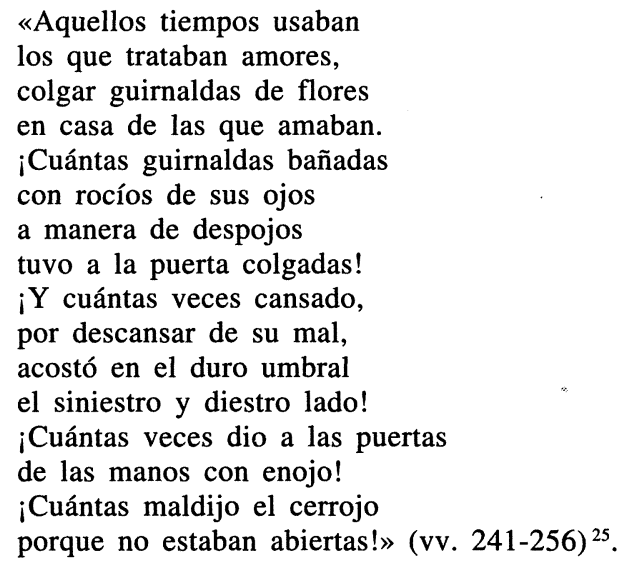

Hurtado de Mendoza amplifica el texto ovidiano de Metamorfosis, donde se recoge el mito citado:

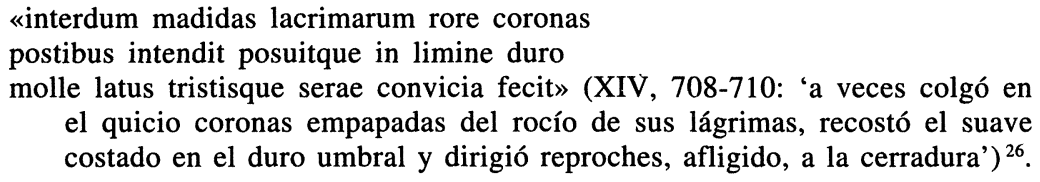

Esta forma literaria en la que se aplica la enseñanza que de un mito se desprende a un caso supuestamente real la emplea ya Ovidio en el texto

${ }^{24}$ Vid. TORRES NAHARRo, Obra completa, p. 420. Salvo advertencia, modernizamos la ortografía, a no ser las grafías de valor fonológico.

${ }^{25}$ Vid. Poesía completa, n. ${ }^{\circ}$ LXXII, p. 177.

${ }^{26}$ Para la completa narración del mito, vid. Metamorfosis, XIV, 699-771. 
citado: en efecto, es una vieja (anus), a modo de tercera, quien narra la historia a Pomona para que se compadezca de Vertumno ${ }^{27}$.

Luis de Camôes escribió un soneto en español en el que pide a la ventana que le permita contemplar a la amada. La invocación a la ventana, en lugar de la puerta, no ha de separarnos del tópico: el ruego, la expresión de la pena amorosa, los obstáculos para el acercamiento a la mujer nos sitúan en el cauce que estamos comentando. He aquí el soneto:

\author{
«Ventana venturosa, do amañece \\ qual resplendor d' Apollo el de mi dama, \\ abrazar-te veja yo con una llama \\ de las con que mi alma resplandece. \\ ¿Por qué se ves el mal que se padece, \\ y sientes el dolor que el pecho inflama, \\ no dexas a mis ojos ver la rama \\ que dientro en mí con lágrimas florece? \\ Si no te mueve ya la pena mía, \\ muévate ver lo poco que se gana \\ de no dexar al alma su alegría. \\ Ya, pues lo sabes, ya, cruda ventana, \\ antes que mi dolor discubra el día, \\ déxame ver mi ninpha soberana» ${ }^{28}$.
}

Cristóbal Mosquera de Figueroa reelaboró el tópico con fidelidad clásica. Apostrofa a la puerta para que le sea clemente y le deje comunicarse con la amada. El texto nos lo ha conservado Fernando de Herrera, en sus comentarios a Garcilaso (1580); el sevillano anota con propiedad: «Y Cristóbal Mosquera de Figueroa en el 5 libro de su enamorado Eliocriso escribe estos versos, convirtiendo a las puertas lo que hablaba con Criselia:

\footnotetext{
'Vos, puertas, sois testigos de mis males, y pudiérades ser también ahora remedio de mis penas desiguales.
}

27 Pero quien empleó tal técnica con particular sabiduría fue Horacio (Ramajo, 1984, pp. 319-320). Para la imitación del procedimiento horaciano en Garcilaso, canción V, con referencia al mito citado, cf. Lázaro Carreter, 1986. El mito de Anaxárete e Ifis será conocidísimo por los ingenios áureos. Lope de Vega lo introducirá frecuentemente en su teatro, a veces de forma sutil, como en el caso que presentamos. El despechado Comendador de Ocaña maldecirá a la inquebrantable Casilda, labradora: « Plega al Amor que te convierta en / piedra!» (acto II, 1856-1857, Peribánez y el Comendador de Ocaña, p. 96).

${ }^{28}$ Obras, II, p. 165. Respetamos fielmente el texto de la edición citada, aun cuando modificamos levemente la puntuación. En este caso no modernizamos las grafías, para acercarnos mejor a la escritura española de Camôes. Nos parece preferible el texto elegido al que presenta la editora Saraiva, 1980-1981, II, p. 449, que, por otro lado, considera incierta la autoría del poema. Modifica la estudiosa citada alguna grafía: Apolo (v. 2), abrasarte (v. 3), ninfa (v. 14). 
Ya da señal de luz la blanca Aurora, puertas, dejadme ver a mis amores, dejadme despertar a mi señora $(. . .)^{\prime}{ }^{29}$.

Nada tiene de extraño que haya dejado muestras del tópico Lupercio Leonardo de Argensola, tan horaciano él. En el famosísimo soneto que comienza «Llevó tras sí los pámpanos octubre», tras una descriptio del otoño y del invierno, reelabora el tópico en el segundo terceto: «Y Fabio, en el umbral de Tais tendido, / con vergonzosas lágrimas lo baña, / debiéndolas al tiempo que ha perdido» (vv. 12-14) ${ }^{30}$ : tono de censura en estos versos contra el loco amor, en aire de comedia sugerido por el episodio y por el nombre de Tais, que remite a una cortesana de Terencio (El eunuco).

Lupercio toca el tema de pasada en otro soneto: en realidad, el poeta quiere trazar una «renuntiatio amoris»:

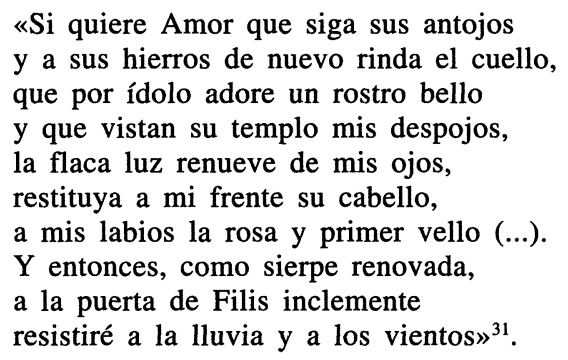

También su hermano Bartolomé dejó muestra del tópico, con intención satírica:

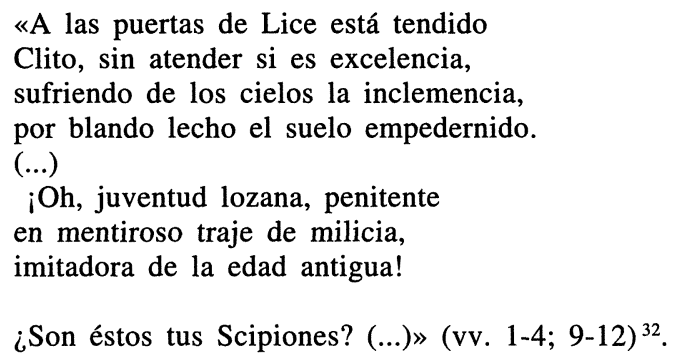

${ }^{29}$ Vid. Fernando de Herrera, Anotaciones a la poesía de Garcilaso, pp. 348-349; véase el texto también en Mosquera de Figueroa, Obras. I. Poesías inéditas, p. 259.

${ }^{30}$ Rimas, n..$^{\circ}$, p. 109. Merece señalarse que este soneto se incluye en ESPINOSA, Flores de poetas ilustres, antología muy marcada por un espíritu horaciano.

${ }^{31}$ Vid. Rimas, n. ${ }^{\circ} 42$, vv. 1-11, p. 68 . Cf. Ramajo, 2001 p. 447, para el sustrato horaciano $\mathrm{y}$, acaso, petrarquista.

${ }^{32}$ Rimas, II, p. 195. 
El espíritu del soneto de Bartolomé no puede ser más clásico: el joven no ha de entregarse por entero al amor. Tiene obligaciones con la patria; entre ellas, de forma muy especial figuran las labores de milicia. Horacio, en III, ii, había puesto en la austeridad y en la vida militar el camino de perfección del joven romano: «Angustam amice pauperiem pati / robustus acri militia puer / condiscat...» (vv. 1-2: 'Que el joven, endurecido por la dura vida de la milicia, aprenda a soportar, de buen grado, una estrecha austeridad'). Para el lector coetáneo a los Argensola era, desde luego, fácil notar el contraste entre el Clito del soneto y las grandes figuras de los tiempos latinos. Y no sólo le vendría el recuerdo de los grandes Escipiones. Seguramente en su mente se guardaría el famoso retrato que de Aníbal traza Tito Livio, en el cual figura un pasaje en que se observa al general cartaginés dedicar al sueño el tiempo en que la lucha no se lo impide: «...vigiliarum somnique nec die nec nocte discriminata tempora; id, quod gerendis rebus superesset, quieti datum; ea neque molli strato neque silentio accersita; multi saepe militari sagulo opertum humi iacentem inter custodias stationesque militum conspexerunt» ("no tenía tiempo preciso para la vigilia o el sueño, ni de día ni de noche; lo que sus ocupaciones le permitían dedicaba al descanso, que no precisaba ni de cama blanda ni de silencio; muchos lo vieron con frecuencia, cubierto con su capote militar, acostado en el suelo, entre los destacamentos de guardas y centinelas'). Esta censura de Bartolomé contra la juventud de su tiempo parece adelantar, por otro lado, las críticas que Jovellanos hará a los desocupados e inútiles nobles de su época.

Sería menester investigar la presencia del tópico no sólo en autores bien conocidos, sino en colecciones poéticas, en las que figuran obras anónimas. En este sentido, acaso sea una muestra de nuestro tema, el título de un poema anónimo recogido en el Cartapacio de Francisco Morán de la Estrella (en él figura, además, el tópico de que los sueños se componen de la misma trama que la vigilia ${ }^{33}$ ): "Otro soneto a una dama que soñó que habían muerto a su puerta al galán que la servía» ${ }^{34}$. He aquí el texto:

${ }^{33}$ Cf Ramajo, 1996, pp. 454-455.

${ }^{34} \mathrm{Cf}$. n. ${ }^{\circ} 923$, p. 449 . No estudiamos el tópico en la lírica tradicional. Nos contentamos con señalar que en el Nuevo Corpus de la antigua lírica popular hispánica, recogido por Margit Frenk, figuran poemas en los que podría brotar el locus literario citado. Véase el núm. 690bis: «Toda la noche velé, / y sin ella me iré» (vol. I, p. 472). Pero, salvo en el señalado, en otros textos es la mujer quien expresa la voz poética: véanse 189, 696 y 698 («Caballero, bien podéis iros, / que en verdad no puedo abriros», vol. I, p. 478). Véase, incluso, una jarcha: «Qué faré, mamma? / Meo al-habib est' ad yana» (vid. Poesía española. 2. Edad Media: Lírica y Cancioneros, p. 89; cf. todavía el comentario de Menéndez Pidal, 1951, pp. 120-123). El tema en tales cancioncillas se reelabora de forma sucintísima. Es posible que guarde alguna relación con el tópico de la lírica culta, pero, con todo, parece seguir su propio camino. Y es que, en palabras del citado Menéndez Pidal, 1951, p. 66, nos encontramos en esas obritas con el «estilo que 
«Por causa natural se comprehende que el mucho imaginar de noche y día ocupa tanto nuestra fantasía que el sueño representa lo que emprende. Así vuestro deseo, que no extiende en más que consumir la vida mía, aun soñando, vivo verme no querría. ¡Mira el aborrecer a dó se extiende! El sueño que soñaste fue figura de lo que yo padezco tan despierto penando en mí el dolor y desventura. No es mucho que padezca en sueños muerte quien nunca tuvo vida más segura que cuando del morir estaba cierto».

Sobre el tópico en Góngora ha escrito Giulia Poggi (1983). Estudia el tema en la canción «iQué de invidiosos montes levantados...!» ${ }^{35}$, y lo anota, además, en el romance 15 (1584), que comienza: «Noble desengaño...». El pasaje, de tono burlesco, en que figura el tópico es el siguiente:
«iQué de noches frías que me tuvo el hielo tal, que por esquina me juzgó tu perro, y alzando la pierna, con gentil denuedo, me argentó de plata los zapatos negros!» ${ }^{36}$.

Habría que investigar otros lugares en que figure el procedimiento. Repararemos en uno solamente: Góngora, en un poema que le es atribuido,

debemos llamar tradicional, común de la colectividad, no estilo personal de un individuo; estilo caracterizado por simplicidad perfecta, esencialidad intensa, liricidad transparente...». En todo caso, sería preciso emprender una investigación más demorada.

${ }^{35}$ Cf. Poggi, 1983, pp. 195-197. En realidad, en la canción gongorina no se cumple la esencia del tópico, por cuanto el pensamiento del poeta entra en la casa de la bella mujer, pero, ciertamente, Góngora toca elementos del tema, como la noche, el intenso frío, los guardianes de la morada: «Ni a las tinieblas de la noche obscura / ni a los hielos perdona [el pensamiento], / y a la mayor dificultad engaña; / no hay guardas hoy de llave tan segura / que nieguen tu persona, / que no desmienta con discreta maña...» (Canciones y otros poemas en arte mayor, $\mathrm{n}^{\circ} \mathrm{VI}, \mathrm{vv} .10-15, \mathrm{p} .88$ ). Véanse el comentario de D. Alonso, 1967, II, pp. 201-204, y Micó, 1990, pp. 84-86.

${ }^{36}$ Cf. Poggi, 1983, p. 195, nota 9. Este interesante romance, de tono burlesco, como hemos dicho, se ha construido empapado de reminiscencias clásicas. Veamos sólo los ocho primeros versos: «Noble desengaño, / gracias doy al cielo / que rompiste el lazo / que me tenía preso. / Por tan gran milagro / colgaré en tu templo / las graves cadenas / de mis graves yerros». La fuente es Horacio, I, v. Pero se produce la contaminatio con Garcilaso, soneto XXXIV: «Gracias al cielo doy que ya del cuello / del todo el grave yugo he desasido...». 
toca el tema de manera obscena, en simultaneidad con otro muy conocido: el de la bella mal maridada. Veamos el fragmento que más nos interesa:

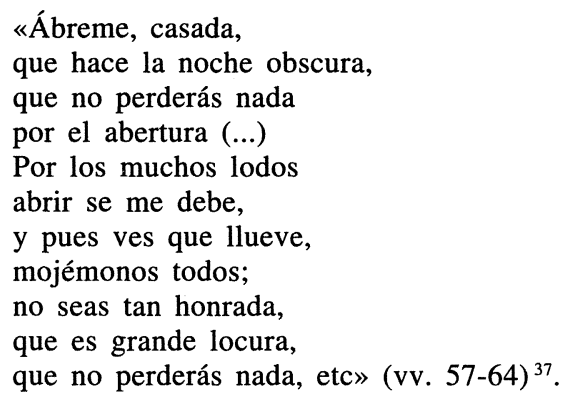

Presentamos algunas muestras de reelaboración del tópico en Lope de Vega, en textos que figuran en conjuntos líricos, teatrales o novelescos.

Lope, en La Filomena (1621), presenta al pastor Silvio enamorado en vano de Filomena, violada por su cuñado Tereo, que le corta la lengua para que no pueda contar la infamia. Silvio canta su pena amorosa antes de arrojarse al mar, en versos que recuerdan los momentos previos al suicidio de algunos personajes de las Heroidas ovidianas. Así anota algunos de sus afanes:

«y en sus puertas la noche me buscaba,

y en las mismas también me hallaba el día» (lib. III, vv. 341-342) ${ }^{38}$

En Rimas de Tomé de Burguillos (1634), Lope reelabora el tópico en el soneto que lleva por título «A la ira con que una noche le cerró su puerta», dentro de «un canzoniere bastante burlesco y gracioso, donde se ponen en chunga todos los tópicos de la poesía amorosa de los siglos XVI y XVII» (Blecua) ${ }^{39}$. El apócrifo Tomé canta:

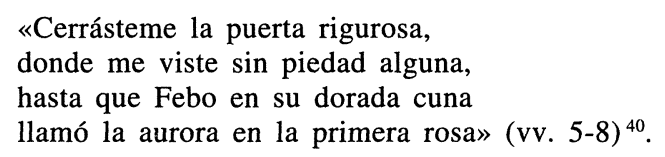

${ }^{37}$ Nuevos poemas atribuidos a Góngora, «Letrillas», VI, pp. 54-55. Para el tema de la mal casada, cf., simplemente, Menéndez Pidal, 1938, pp. 21-23. Véase el texto del famoso romance de «La bella mal maridada», con útiles comentarios, en Alonso y Blecua, 1964, pp. 14 y 256. El tema es raro en la poesía latina medieval, según Szövérffy, 19921995, III, p. 293.

${ }^{38}$ Vid. Obras poéticas, p. 612.

${ }^{39}$ Cf. Blecua, 1976, p. XLIII.

40 Vid. Obras poéticas, p. 1345. En Rimas, Lope se sirve de un elemento del tópico: la apóstrofe a la puerta: «¡Ay dulce puerta, en cuyo mármol cargas, / dueño cruel, las armas homicidas, / empresa y sepultura de las vidas, /que para fin tan miserable alargas! (soneto 119, Obras poéticas, pp. 93-94). 
Convendría investigar con sosiego la aparición del tópico en el teatro del Fénix. Es obvio que la labor resulta ardua. Nosotros aquí agrupamos unas escasas apariciones encontradas en nuestras lecturas.

En Laura perseguida (1594) Lope toma elementos del tópico: el príncipe Oranteo se ha apartado de su amada Laura ante la imposibilidad aparente de casarse con ella: se lo impiden su padre y la mala fama que de ella le ha llegado. Con todo, impulsado por un fuerte amor que lucha contra el sentimiento del honor, persevera en pasear en las cercanías de la casa de la mujer, hasta el punto de que Octavio, secretario, le advierte:

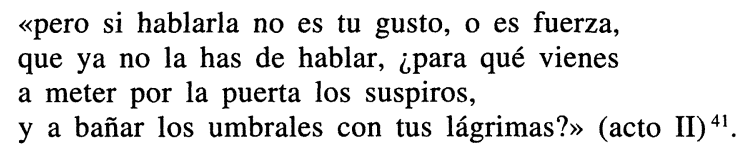

En El genovés liberal (1599-1608) el tópico emerge claramente. Otavio (sic) se esfuerza por conseguir el amor de Alejandra, quien, verdadero ejemplo de casadas, como diría el título de otra comedia lopesca, se mantiene fiel a su esposo Camilo. De aquí que Otavio, frustrado al ver que la ausencia del marido no le aprovecha, exclamará:

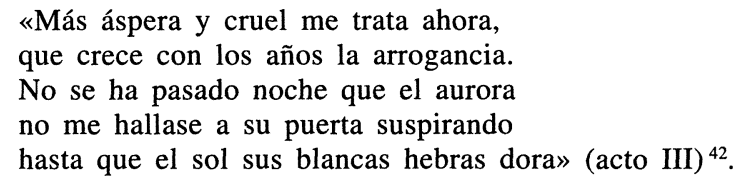

Otavio imagina incluso que será enterrado en la misma puerta de su amada. Su fidelidad contrasta con la del voluble amante horaciano de III, x. Parece como si la ejemplar Alejandra se tornara una Anaxárete:

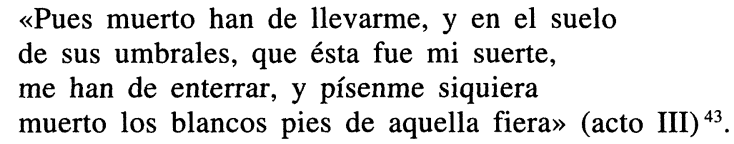

${ }^{41}$ Cf. Comedias, I, p. 405 (no registramos la numeración de los versos porque la edición consultada la omite). Pocos versos antes, Oranteo se dirige a la puerta, personificada así, como en el tópico, aunque él no pretenda franquearla: «Puertas de mi Laura hermosa, / calle donde me perdí...» (acto II, p. 403). En un momento posterior, Oranteo dialoga con su amada y le confiesa: «que sabe Dios que a tu puerta / más de una noche he dormido» (acto II, p. 430). No se piense, con todo, que Laura no le ha dejado entrar; él no lo ha intentado, pues no se atrevía a verla, dada la mala opinión que de ella malas lenguas le habían forjado.

${ }_{42}$ Comedias, $X V$, p. 353. Ya antes había apostrofado: «iAh, puertas del alma mía, / tened lástima de mí! / (...) ¡Voyme, y vive el cielo, puertas, / que os tengo de combatir!» (Acto II, p. 549).

${ }^{43}$ Comedias, $X V$, p. 371. 
El exclusus amator quiere persistir en su queja más allá de la muerte, en la vecindad temática del «Amor constante más allá de la muerte» de Quevedo («Cerrar podrá mis ojos la postrera / sombra...»).

En Los amantes sin amor (1601-1603), Lope presenta dos personajes que están fingiendo amor. Don Lorenzo - el que a nosotros nos interesa por tener relación con nuestro tema- escenifica el embuste a petición de su amigo Felisardo, que desea probar a su prometida Octavia. La trama recuerda la que desarrollará Cervantes en El curioso impertinente. Pero Lope dará buen fin a su obra: todos los enamorados alcanzarán matrimonio al término de la comedia, sin que haya habido amores ilícitos. En un determinado momento, Octavia refrena la supuesta pasión de don Lorenzo y le desenmascara al recordarle, con elementos del tópico estudiado, su falta de sacrificio:

$$
\begin{aligned}
& \text { «Qué noche habéis dejado } \\
& \text { de dormir por este amor? } \\
& \text { ¿Qué hielos habéis sufrido } \\
& \text { en esa puerta? (...)» (acto II) }{ }^{44} \text {. }
\end{aligned}
$$

En El hombre de bien (1604-1606), el Rey, prendado de Lucinda, al tiempo que mantiene relaciones con otra dama, Clavela, no consigue los favores de la primera, que, a la postre, conseguirá casarse públicamente con Jacinto, quien se denominaba a sí mismo «el hombre de bien», para esconder el nombre auténtico. El tema estudiado en nuestro trabajo aparece en dos ocasiones. En la primera, el Rey se dirige a Lucinda:

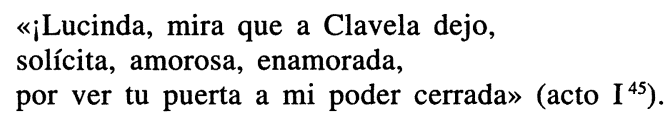

En la segunda, Clavela cuenta a Lucinda:

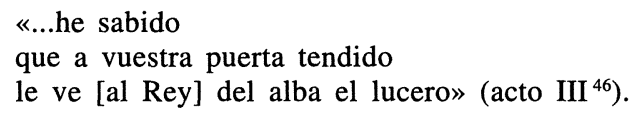

Curiosa manifestación del tópico, en la que el poder real, absoluto, choca, ineficaz, contra la endeblez de las puertas de la amada.

Parece haber alusión al tópico en dos lugares de Peribáñez y el Comendador de Ocaña. En el primero, el Comendador suplica a la labradora Casilda:

${ }^{44}$ Comedias, XII, p. 269.

${ }^{45}$ Comedias, XIII, p. 926.

${ }^{46}$ Comedias, XIII, p. 971. 


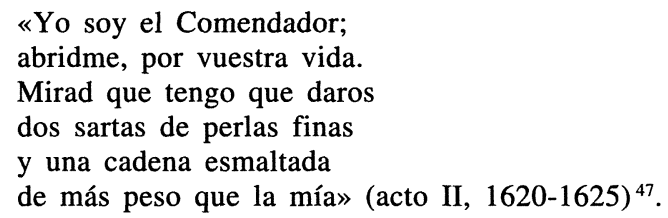

En el segundo lugar, se queja el Comendador de la dureza de la labradora:

\author{
« ¿Rigurosa mujer! ¡Maldiga el Cielo \\ el punto en que caí, pues no he podido \\ desde entonces (...) levantarme \\ de los umbrales de su puerta!» (acto II, 1822-1825) ${ }^{48}$.
}

El villano en su rincón (¿1614-1616?) recoge un debate entre dos labradores, con la comicidad propia de los graciosos, Bruno y Salvano, consistente en demostrar quién ha recibido más favores de Belisa. Se trata de un remedo de los versos amebeos pastoriles, en que cada personaje responde a otro con una estructura paralela pero con un contenido semántico antitético. En este debate figura un juez, Fileto, que a nadie da la palma (vid. v. 1462), imitación acaso de Virgilio ${ }^{49}$. Salvano reelabora burlescamente el tópico:

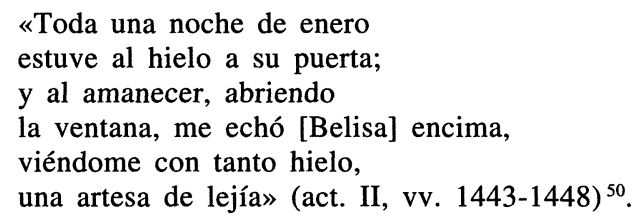

${ }_{47}$ Peribáñez y el Comendador de Ocaña, p. 87.

48 Peribáñez y el Comendador de Ocaña, p. 95.

${ }^{49}$ En la bucólica III, 108-109, de Virgilio, Palemón, que hace de juez, considera dignos de la victoria y del premio tanto a Menalcas como Dametas: «Non nostrum inter vos tantas componere lites; / et vitula tu dignus et hic...» ('No es cosa nuestra dirimir tan gran contienda entre vosotros; de la ternera tanto tú como éste sois dignos...').

${ }^{50}$ El villano en su rincón, p. 145.

En El piadoso veneciano (1599-1608) puede aludirse al tema, dentro del tópico de la militia amoris: «...en el amor hay velas, / hay sospechas, hay espías, / y en noches de invierno frías / cuidadosas centinelas» (Acto II, Comedias, XV, p. 524). En la misma comedia Otavio apostrofará a las puertas de su amada Elisa, hija de Sidonio, homicida de su padre Fulgencio: «Puertas de mi dulce amiga, / hija de aquel mi enemigo, / que para mayor castigo / quiere el cielo que os persiga» (acto III, Comedias, XV, p. 569).

En La bella malmaridada o la cortesana (antes de 1598) figura la apóstrofe al portero (correspondiente al «ianitor» ovidiano, antes visto): «Oh tú de mi gloria cierta, / portero, llave, y amigo, / dame esos brazos y fía / de mi alma el galardón!» (acto III, 2924-2927, p. 140). Se trata, en este caso, de un falso portero: es el disfrazado marido que pretende desenmascarar a Cipión, quien intenta enamorar a su esposa Lisbella, fidelísima, por cierto. 
En La vida de San Pedro Nolasco (después de 1618) Teresa cuenta cómo el rey don Jaime de Aragón (Jaime I el Conquistador) ha perseguido su amor. Ella no le ha permitido la entrada a la casa hasta que el enamorado ha hecho promesa de matrimonio:

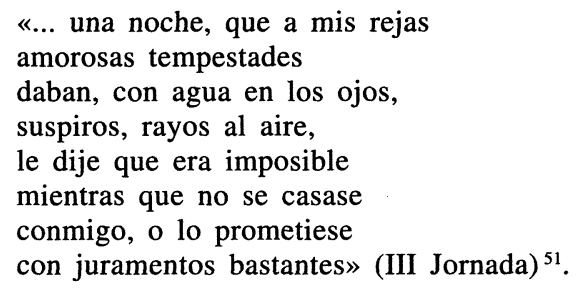

Muy curioso resulta el tratamiento del tópico en El rústico del cielo (1605). La acción evangelizadora de Francisco, hombre santo de escasas dotes intelectuales, resulta tan eficaz que hasta las mujeres de vida ligera cierran las puertas a los suplicantes enamorados de ocasión. Véase el diálogo entre Juan y Justina:

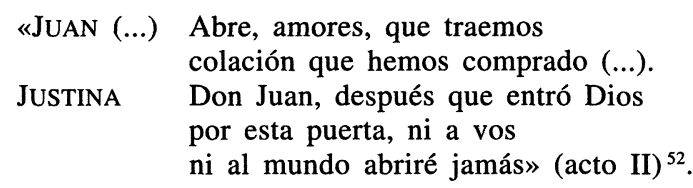

En El leal criado (1594) el enamorado Leonardo dice: «Miradme, ;oh puertas y rejas, / testigos de tantas quejas / y de tan altas venturas» (acto II, Comedias, I, p. 498). Pero, en realidad, Leonardo no es rechazado por su amada Serafina, con la que contraerá matrimonio.

También parece haber alusión al tema en Los embustes de Fabia (antes de 1596). Brisena, dama aparentemente amada por Vitelio, reconoce el engaño de éste, y le dice: « iNi me busques ni me veas, / ni solamente me nombres; / y no me toque [sic] a la puerta, / que haré a la puerta matalle!» (Jornada III, Comedias, I, p. 892).

Lo mismo acontece en El testigo contra sí (1605-1606): Lisardo se casará al final de la obra con su amada Estela; pero antes ha sufrido muchos accidentes. De aquí, que en un momento grite: « Malditas las puertas sean, / las paredes y los techos / que te encierran y te encubren / cuando te llamo y deseo!» (acto III, Comedias, XIV, p. 178).

En Los Prados de León (¿1604-1606?), Nuño intenta ver, en la corte, a su amada Nise. Y se dirige, no a la puerta, sino a las paredes: «Mármoles, doleos de mí, / pues que Nise no responde» (acto III, Comedias, XIV, p. 859). Poco después, Nuño se dirige a un portero (el ianitor del tópico) para que avise a Nise (cf. pp. 862-863). Éste es obediente, no como en la tradición literaria clásica.

${ }^{51}$ Obras de Lope de Vega, XI, ii, p. 94. Al final, el rey estaba dispuesto a cumplir su palabra matrimonial, por petición de San Pedro Nolasco. Pero Teresa prefiere enclaustrarse. Así se salva un problema: la diferencia de altura en el linaje de los enamorados.

${ }^{52}$ Vid. Comedias, XIII, p. 458. 
El amante rechazado reconocerá la fuerza divina, y renunciará por propia voluntad a entrar en la casa, pues no quiere «hurtar / fruta en jardines de Dios» ${ }^{53}$.

En los poemas que inserta Lope en sus novelas aparece en alguna ocasión el tópico. En La Arcadia (1598), lib. I, el pastor Celio cuenta su itinerario amoroso. Se enamora de niño de Jacinta. Crecen la edad y el amor. Pero Jacinta se casará con un amigo del pastor citado. Celio entra en un estado de locura que recuerda la del Albanio, de la égloga II de Garcilaso. El tópico del exclusus amator brota fugacísimo en el relato:

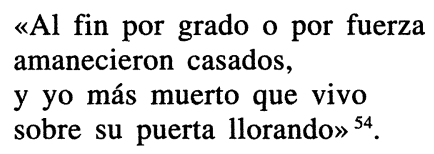

En la propia Arcadia, lib. III, dos pastores representan una égloga. El llamado Lucindo expone así su amor profundo por Albania:

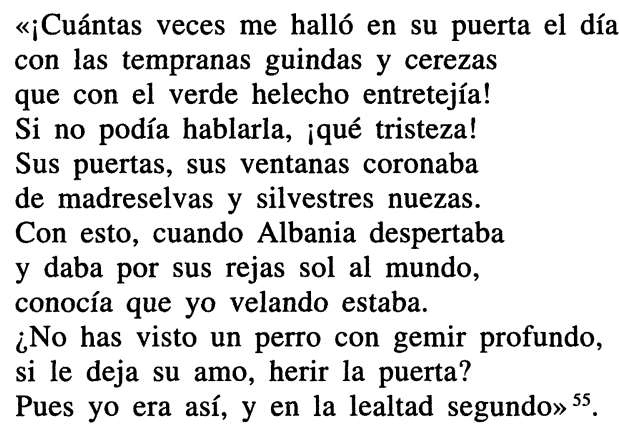

Las ofrendas y adornos de la puerta, la vela prolongada, la dureza pétrea de la amada, retrato de la ninfa Anaxárete, nos sitúan de lleno en el corazón del tópico.

En el auto del Viaje del alma, que cierra el libro I de la novela de $E l$ peregrino en su patria (1604), se presenta a Cristo como un amante que espera que el alma le abra su puerta, como acontecerá con el soneto que comienza « ¿Qué tengo yo que mi amistad procuras?:

${ }^{53}$ Comedias, XIII, p. 459. Dentro de la relación del tópico con el espíritu religioso, ha de citarse el planteamiento que figura en El saber por no saber, y vida de San Jualián de Alcalá de Henares (posterior a 1618): Julián se ve expulsado del convento de franciscanos donde ansía vivir, y semeja a un exclusus amator a la puerta del convento, en la que piensa permanecer hasta la muerte: «Pero mi amor se asegura, / que seré en aqueste umbral, / cual suele el perro leal / morir sobre sepultura...» (acto I, Obras de Lope de Vega, XI, ii, p. 340).

${ }^{54}$ La Arcadia, p. 126 (la ed. citada no numera los versos).

55 La Arcadia, pp. 286-287. 
«Decilde al Alma que aguarde, si arrepentida me ama; llegue a mí, no se acobarde, que nunca yo vengo tarde, puesto que tarde me llama. A la puerta estoy llamando; si mi voz la está tocando, y me la abriere, entraré; por gran precio la compré, por eso la voy buscando» ${ }^{56}$.

Nos encontramos con un tratamiento del tópico «a lo divino».

En Las Fortunas de Diana ${ }^{57}$, novelita inserta en La Filomena (1621), dedicada a Marcia Leonarda (es decir, Marta de Nevares), Lope de Vega detiene en un determinado momento la narración en prosa y entrevera ver$\operatorname{sos}^{58}$. El pastor Fabio en un tiempo no abrió la puerta a Filis, por no creer en su amor. Después, la pastora, enamorada de Silvio, parece vengarse: ahora es ella quien no permite el acceso del primer pastor a su cabaña, que se lamenta:

\author{
«¡Oh, cuántas noches que dije, \\ cuando a mi puerta llamabas:

56 Vid. El peregrino en su patria, p. 135. Para la posible plasmación «a lo divino» del tópico en el soneto ya citado («¿Qué tengo yo que mi amistad procuras?»), cf. Ramajo, 1993 y 2000, p. 334. Véanse, para otros planteamientos, Lapesa, 1977 y Cuevas, 1981.

57 Obras poéticas, pp. 674-676.

${ }^{58}$ Lope comenta la inserción de una historia secundaria en verso dentro del curso principal novelesco en prosa: «y vuestra merced, señora Leonarda, si tiene más deseo de saber las fortunas de Diana que oír cantar a Fabio, podrá pasar los versos deste romance sin leerlos...» (Obras poéticas, p. 674). Para excursos en esta y otras novelas dedicadas a la misma persona, cf. Rico, 1968, pp. 14-17.

${ }^{59}$ Para la popularidad de este romance, cf. Rico, 1968, 182. Eco de este estribillo lopesco se encontrará, además, en el poeta del XVIII, José Iglesias de las Casas, letrilla IV: «'En vano a la puerta llama / quien no llama al corazón'» (Poetas líricos del siglo $X V I I I$, vol. LXI, p. 421). En esa letrilla, el poeta Iglesias adapta el tópico a la realidad española: «Zagal, tus cantares deja; / no el dulce silencio alteres, / ni te quejes a mujeres, / que no han de escuchar tu queja; / cesa de observar la reja, / que rondas sin ocasión» (Ibid.). 
Sin duda, la inmensa obra de Lope aportará otros textos en los que figurará el tópico. Sería menester inventariarlos. Pero en este trabajo preciso es acercarnos a autores diversos.

Juan de Arguijo presenta el tema con sabor horaciano, pero más de epodo que de oda, por un cierto tono acre y desengañado (a la manera barroca, por otro lado) y por la etopeya de la mujer, de muy baja catadura moral, que no sólo se muestra esquiva, de acuerdo con la tradición petrarquista ${ }^{60}$, sino incluso gozosa al contemplar las desdichas del enamorado. El retrato de esta amada cruel nos introduce, en efecto, en la tradición literaria: vienen, además, el recuerdo de Garcilaso, canción V, de Anaxárete: «Estábase alegrando / del mal ajeno el pecho empedernido» (vv. 71-72), y el recuerdo del moralista Fray Luis, que amonesta a Cherinto contra «la engañosa / Circe...» (IX, 21-22). Véanse los versos de Arguijo:

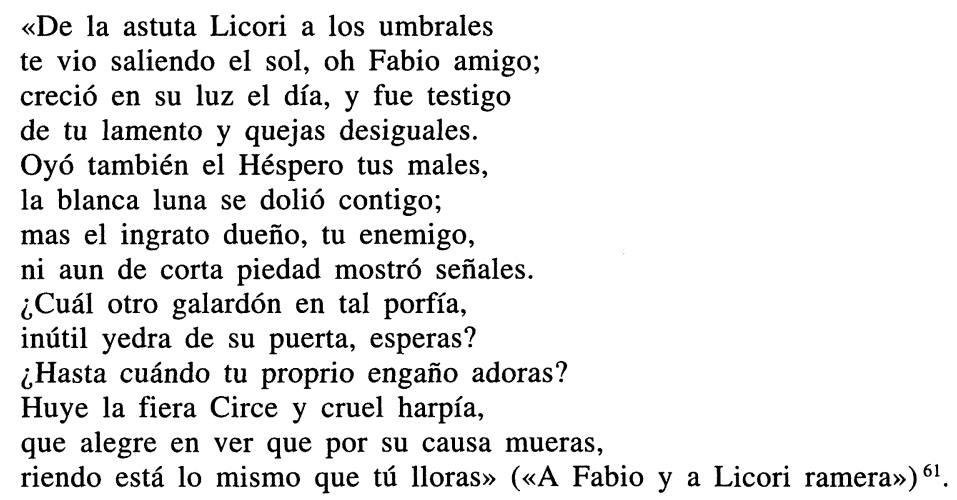

También Quevedo dejó muestras del tópico. Así, el poema titulado «A la puerta de Aminta» lo construye a base de una retractatio a partir del poema de Tibulo I, ii, que antes hemos citado. Si el poeta latino maldecía a la puerta por no franquearse, Quevedo le desea ventura a cambio de su benevolencia:

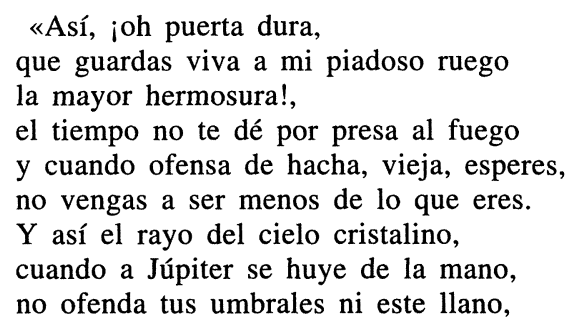

${ }^{60}$ Cf. Ramajo, 2002b.

${ }^{61}$ Cf. Obras poéticas, n. ${ }^{\circ}$ LII, p. 135. 


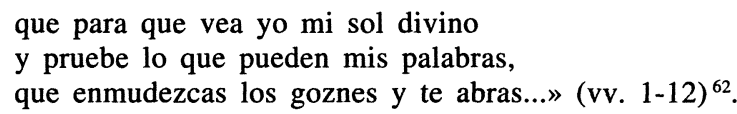

Otra muestra quevediana es el soneto titulado «Venganza en figura de consejo a la hermosura pasada»:

\author{
«Ya, Laura, que descansa tu ventana \\ en sueño que otra edad tuvo despierta \\ $\mathrm{y}$, atentos los umbrales de tu puerta, \\ ya no escuchan de amante queja insana» (vv. 1-4) ${ }^{63}$.
}

Se trata de una reelaboración de Horacio, I, xxv, 1-7: «Parcius iunctas quatiunt fenestras / ictibus crebris iuvenes protervi, / nec tibi somnos adimunt, amatque/ ianua limen,/ quae prius multum facilis movebat/ cardines» ('Raramente ya los jovenzuelos desvergonzados azotan las cerradas ventanas con frecuentes golpes, y ya no te roban el sueño; y la puerta reposa en el umbral, la puerta que antaño muy benévola giraba en los goznes') ${ }^{64}$.

Francisco de Rioja se inspira fielmente en la citada oda horaciana III, $\mathrm{x}$ («Extremum Tanain si biberes, Lyce...») ${ }^{65}$ :

\author{
«Aunque pisaras, Fili, la sedienta \\ arena qu'en la Libia Apolo enciende \\ sintieras, ¡ay!, que el Aquilón me ofende, \\ y del yelo y rigor la pluvia lenta. \\ Oye con qué rüido la violenta \\ furia del viento en el jardín $\mathrm{s}^{\prime}$ extiende. \\ y que apena aun la puerta se defiende \\ del soplo que en mi daño se acrecienta. \\ Pon la soberbia,joh, Fili!, y blandos ojos \\ muestra, pues ves en lágrimas bañado \\ el umbral que adorné de blanda rosa; \\ que no siempre tu ceño y tus enojos \\ podré sufrir, ni el mustio ivierno helado, \\ ni del Bóreas la saña impetuosa» ${ }^{66}$.
}

${ }^{62}$ Cf. Obras completas, p. 443. Orobitg, 1996, p. 416 ve el origen del ruego amatorio a la puerta en Plauto, Curculio, I, vv. 87-95. En el último verso citado, Quevedo sigue fielmente a Tibulo: «Neu furtim verso cardine aperta sones» (II, i, 10: 'que, al abrirte, no chirríen los goznes en su giro').

${ }^{63}$ Cf. Obras completas, p. 343.

${ }^{64}$ Cf. la buena nota de Schwartz y Arellano, 1998, p. 744.

${ }^{65}$ Cf. Cristóbal, 1990, p. 267, y Ramajo, 1993, pp. 621-622.

${ }^{66}$ Véase Francisco de RiOJA, Poesía, p. 148. Por otro lado, la oda horaciana ha motivado, además, influjos en Pedro Soto de Rojas (vid. «Noche de invierno en su puerta», vv. 31-50, Obras, pp. 99-100: cf. Menéndez Pelayo, 1883, p. 100) y Villegas (vid. n. ${ }^{\circ} 16$ de Eróticas o Amatorias, pp. 32-33: cf. Ramajo, 1993, pp. 622-623), y traducciones en español, como la de Fray Luis de León («Aunque de Sctia fueras, / y aunque más bravo fuera tu marido...»: vid. Poesía completa, pp. 419-420), la de Medrano («Ode» 
El tópico que estamos estudiando pervivió muchos años después de los Siglos de Oro, aunque ya aparezca de manera ocasional, según, al menos, nuestras pesquisas. Alguna muestra dejó el muy clásico poeta Juan Meléndez Valdés:

« $i$ ué de veces en lágrimas bañado me halló el alba besando tus umbrales, o la lóbrega noche, siempre iguales mi ciego anhelo y tu desdén helado!» («El propósito inútil», vv. 5-8) ${ }^{67}$.

De nuevo introduce el tema en la oda XII, «La reconciliación», calcada de la horaciana, III, ix («Donec gratus eram tibi»). Dialogan Lidia y Fileno:

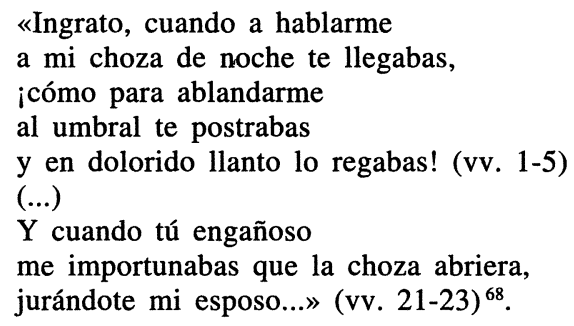

La inminente unión amorosa anuncia el fin de la oda.

Todavía surge el tema en los umbrales del Romanticismo, en José Somoza (1781-1852), poeta estimable, buen conocedor de Horacio:

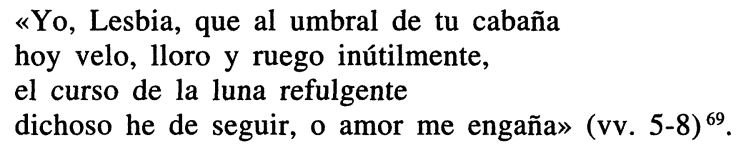

El poeta siente envidia de la luna, que entra en la cabaña de la amada e ilumina su cuerpo, y espera, como el astro, poder tocar el cuerpo de Lesbia, aunque de forma casta, con la castidad propia - digamos nosotrosde la luz lunar (la luna no es sino Diana) ${ }^{70}$.

La presencia del tópico en las letras hispanas se dilata, pues, durante

IX, Poesía, pp. 215-216) o la de Luis Martín, incluida en Pedro Espinosa, Primera parte de las flores de poetas ilustres de España (1605), fols. $150 \mathrm{v}^{\circ} .-151$ (vid. algunos datos más precisos en Ramajo, 1993, pp. 622-623).

67 Obras en verso, I, p. 458.

${ }^{68}$ Obras en verso, II, 638-639. Para el tópico en Meléndez, cf. ya Ramajo, 2002a, pp. 50-51.

${ }^{69}$ Poetas líricos del siglo XVIII, III, p. 465.

${ }^{70}$ Hay en los versos una sensualidad que recuerda a Ovidio y a Meléndez Valdés, aunque la contención de Somoza lo diferencia, al fin, de aquellos poetas. 
un buen tiempo. Y, como se ha visto, se transparenta en lugares diferentes y con acentos diversos. Salta de la lírica al teatro; regala un cauce exquisito para expresar con énfasis la intensidad de la pena amorosa, en la estela de los elegíacos latinos; convive con la admonición moral al amante de crítica por la pérdida de tiempo en el sufrimiento afectivo; se casa con una sensualidad erótica de tono ovidiano; y se deja empapar de sentido religioso en textos que marcan el paso del amor humano al divino. No falta, además, en el tratamiento del tema, a veces, el tono burlesco y obsceno. En todo caso, los autores españoles recorren un camino que le ofrecía ya la rica tradición grecolatina.

Pero también para la historia del tópico supone un cambio el advenimiento del llamado Romanticismo. En Espronceda o Ventura de la Vega, escritores de otra generación posterior a la de Somoza, formados todavía bajo la férula del latín, en los que resultạ fácil descubrir artificios retóricos de Horacio o Virgilio, ya no brota el tópico ${ }^{71}$. Poco a poco, lentamente, se adelgaza la fuerza educadora de la tradición clásica.

\section{REFERENCIAS BIBLIOGRÁFICAS}

AlciNA, Juan F., «Tendences et caractéristiques de la poésie hispano-latine de la Renaissance», en L'Humanisme dans les lettres espagnoles, ed. de A. Redondo, París, Librairie Philosophique J. Vrin, 1979, pp. 133-149.

Alonso, D., y Blecua, J. M., Antología de la poesía española. Lírica de tipo tradicional (1964), 2. ${ }^{a}$ ed. corr., 4. ${ }^{a}$ reimpr., Madrid, Gredos, 1992.

ALONSO, D., 1967: véase Góngora.

ALVAR EZQUERRA, A., «Intertextualidad en Horacio», en Horacio, el poeta y el hombre, ed. de Dulce Estefanía, Madrid, Ediciones Clásicas, 1994, pp. 77-140.

Antologia Palatina, ed. de Filippo Mario Pontani, Turín, Giulio Einaudi, 1978-1981, 4 vols.

Antología Palatina: véanse Poemas de amor y muerte en la Antología Palatina.

ARgensola, Bartolomé Leonardo de, Rimas, ed. de J. M. Blecua (Clásicos Castellanos, 184-185), Madrid, 1974, 2 vols.

Argensola, Lupercio Leonardo de, Rimas, ed. de J. M. Blecua (Clásicos Castellanos, 173), Madrid, 1972.

ArguiJo, Juan, Obra poética, ed. de S. B. Vranich (Clásicos Castalia, 40), Madrid, 1971.

ARNAldi, F., y Gualdo RoSA, Lucía, eds., Michele Marullo, Poliziano, Iacopo Sannazaro. Poesie latine, Turín, Giulio Einaudi, 1976, 2 vols.

Bucólicos griegos, trad. de M. García Teijeiro y M. ${ }^{\mathrm{a}}$ Teresa Molinos Tejada (Biblioteca Clásica Gredos, 95), Madrid, 1986.

CAMÔES, Luis de, Obras, ed. do Visconde de Juromenha, Lisboa, Imprensa Nacional, 1861 , vol. II.

Lírica completa, ed. de María Lurdes Saraiva, Lisboa, Imprensa Nacional, 1980-1981, 3 vols.

CARREIRA, 1998: véase Góngora, Luis de.

${ }^{71}$ Cf., para la huella horaciana en Espronceda, Ramajo, 2003. 
Cartapacio de Francisco Morán de la Estrella, ed. de R. A. Di Franco, J. J. Labrador, C. A. Zorita, Madrid, Patrimonio Nacional, 1989.

Copley, F. O., Exclusus Amator. A Study in Latin Love Poetry (American Philological Association Monographs), Nueva York, 1956.

CRISTÓBAL, 1990: véase Horacio.

Cuevas, C., «El tema sacro de La ronda del galán (¿Fray Luis fuente de Lope?)», en Academia Literaria Renacentista. I. Fray Luis de León, Salamanca, Universidad, 1981, pp. 147-169.

ESPINOSA, Pedro, Primera parte de las flores de poetas ilustres de España (1605), ed. facsímil, Madrid, Real Academia Española, 1991.

FEDELI, P., 1980: véase Propercio.

FERRATÉ, 1968: véanse Líricos griegos arcaicos.

FRENK, Margit, Nuevo Corpus de la antigua lírica popular hispánica (siglos XV a XVII), México, Universidad Nacional Autónoma, 2003, 2 vols.

Góngora, Luis de, Góngora y el "Polifemo», estudio y ed. de D. Alonso, Madrid, Gredos, 1967, 3 vols.

- Canciones y otros poemas en arte mayor, ed. de J. M. Micó (Clásicos Castellanos, 20), Madrid, 1990.

-, Nuevos poemas atribuidos a Góngora, ed. de A. Carreira, Barcelona, Sirmio, 1994.

-, Romances, ed. crítica de A. Carreira, Barcelona, Quaderns Crema, 1998, 4 vols.

GONZÁLEZ-HABA, 1996: véase Plauto.

HENDERSON, W. J., «The Paraklausithyron motif in Horace's odes», Acta Classica, 16, 1973, pp. 51-67.

Herrera, Fernando de, Anotaciones a la poesía de Garcilaso, ed. de Inoria Pepe y José M. ${ }^{\text {a }}$ Reyes, Madrid, Cátedra, 2001.

Horacio, Odes et épodes, ed. de F. Villeneuve, 9. ${ }^{\text {a }}$ reimpr., París, «Les Belles Lettres», 1970.

-, Odas y Epodos, ed. de M. Fernández-Galiano y V. Cristóbal, Madrid, Cátedra, 1990.

Hurtado De Mendoza, Diego, Poesía completa, ed. de J. I. Díez Fernández, Barcelona, Planeta, 1989.

LAPESA, R., «Presencia de Fray Luis en el soneto de Lope '¿Qué tengo yo que mi amistad procuras?'», en Poetas y prosistas de ayer y de hoy, Madrid, Gredos, 1977, pp. 178185.

LÁzaro Carreter, F., «La Ode ad Florem Gnidi de Garcilaso de la Vega», en Garcilaso. Actas de la IV Academia Literaria Renacentista (2-4 de marzo de 1993), ed. de V. García de la Concha, Salamanca, Universidad, 1986, pp. 109-126.

León, Luis de, Poesía completa, ed. de José Manuel Blecua, Madrid, Gredos, 1990

Líricos griegos arcaicos, ed. de J. Ferraté, Barcelona, Seix Barral, 1968.

LUCK, G., La elegía erótica latina, trad. española de A. García Herrera, Sevilla, Universidad, 1992.

Medrano, Francisco, Poesía, ed. de D. Alonso, Madrid, Cátedra, 1988.

MELÉNDEZ VAldÉs, Juan, Obras en verso, ed. de J. H. R. Polt y J. Demerson, Centro de Estudios del siglo XVIII, Oviedo, 1981-1983, 2 vols.

MenÉndez Pelayo, M., Horacio en España (1883), reimpr. en Bibliografía hispanolatina clásica, Madrid, CSIC, 1951, vol. VI.

MENÉNDEZ PIDAL, R., Flor nueva de romances viejos (1938), 18. ${ }^{a}$ ed. (Austral, 100), Buenos Aires, 1969.

-, «Cantos románicos andalusíes», Boletín de la Real Academia Española, 31, 1951, pp. 187-270. Se cita por: R. MENÉNDEZ PIDAL, España, eslabón entre la cristiandad y el Islam, 2. ${ }^{a}$ ed. (Colección Austral, 1280), Madrid, Espasa-Calpe, 1968, pp. 61-153.

Micó (1990): véase Góngora. 
Mosquera De FigueroA, Cristóbal, Obras. I. Poesías inéditas, ed. de G. Díaz-Plaja, Madrid, Real Academia Española, 1955.

Musae reduces. Anthologie de la poésie latine de la Renaissance, ed. de P. Laurens y Claudie Balavoine, Leiden, Brill, 1975, 2 vols.

OROBITG, Cristine, «Exclusus amator: en torno a un poema de Quevedo ('A la puerta de Aminta')", en Studia Aurea. Actas del III Congreso de la AISO, GRISO-LEMSO, Pamplona-Toulouse, 1996, vol. I, pp. 415-424.

ORTEGA, A., El despertar de la lírica en Europa, Salamanca, Universidad Pontificia, 1974.

Oxford Book of Medieval Latin Verse, The, ed. de F. J. E. Raby, reimp., Oxford, At the Clarendon Press, 1984.

Pedrosa, J. M., «'Cuando paso por tu puerta...', análisis comparatista de un poema de Miguel Hernández», Nueva Revista de Filología Hispánica, 50, 2002, pp. 203-215.

Plauto, Comedias, trad. de Mercedes González-Haba (Biblioteca Clásica Gredos, 218), Madrid, 1996, vol. II.

Poemas de amor y muerte en la Antología Palatina, trad. de C. Rodríguez Alonso y Marta González González, Madrid, Akal, 1999.

Poesía española. 2. Edad Media: Lírica y Cancioneros, ed. de V. Beltrán, Barcelona, Crítica, 2002.

Poetas líricos del siglo XVIII, ed. de L. A. de Cueto (Biblioteca de Autores Españoles, LXI, LXIII y LXVII), Madrid, Atlas, 1952-1953.

PogGI, Giulia, “'Exclusus amator' e 'poeta ausente': alcune note ad una canzone gongorina», Linguistica e Letteratura, VIII, 1983, pp. 189-222.

PRoPercio, Sesto Properzio. Il primo libro delle Elegie, ed. y comentarios de P. Fedeli, Florencia, Leo S. Olschki, 1980.

Quevedo, Francisco de, Obras completas. I Poesía original, ed. de J. M. Blecua, 2. ${ }^{\text {a }}$ ed., Barcelona, Planeta, 1968.

-, Un Heráclito cristiano, canta sola a Lisi y otros poemas, ed. de L. Schwartz e I. Arellano, Barcelona, Crítica, 1998.

RABY, F. J. E., 1984: véase Oxford Book of Medieval Latin Verse, The.

RAMAJo CAÑo, A., «Cultura clásica y cristiana en un poema de Fray Luis de León: 'De la Magdalena'», Studia Philologica Salmanticensia, 7-8, 1984, pp. 303-320.

-, «Anotaciones clásicas y cristianas a un soneto de Lope (“QQué tengo yo que mi amistad procuras?'), Epos, 9, 1993, pp. 619-629.

-, «Las huellas clásicas en un poema de Lope de Vega ('En la muerte de Baltasar Elisio de Medinilla')», en Studia Aurea. Actas del III Congreso de la AISO, ed. de I. Arellano y otros, Toulouse-Pamplona, 1996, pp. 449-456.

-, «La codificación de la vida en la poesía áurea. La huella clásica», en Ch. Strosetzi, ed., Aspectos históricos y culturales bajo Carlos V. Aspekte der Geschichte und Kultur unter Karl V, Frankfurt am Main, Vervuert-Iberoamericana, 2000, pp. 325-345.

-, «La renuntiatio amoris en un soneto de Herrera», en Nuevas aportaciones al estudio de la lengua española, Salamanca, Luso Española de Ediciones, 2001, pp. 445453.

-, «Aspectos del sustrato clásico en la poesía de Meléndez Valdés», Revista de Literatura, 64, 2002a, pp. 41-61.

-, «'... De mi dichoso mal la rica historia': itinerario amoroso en el cancionero herreriano (1582)», Criticón, 86, 2002b, pp. 5-19.

- «El sustrato horaciano en un poema romántico: la Canción del pirata de Espronceda», Anuario de Estudios Filológicos, 26, 2003, pp. 325-334.

RICO, F., 1968: véase Vega, Lope de.

Rioja, Francisco de, Poesía, ed. de Begoña López Bueno, Madrid, Cátedra, 1984. 
Rodríguez Alonso, C., y GonZÁlez GonZÁlez, Marta (1999): véanse Poemas de amor y muerte en la Antología Palatina.

ROSENSTEIN, Roy, «The voiced and the voiceless in the Cancioneiros: the muslim, the jew, and the sexual heretic as exclusus amator», La Corónica, 26, 1998, pp. 65-75. SARAIVA, 1980-1981: véase Camôes, Luis de.

SCHMELING, G., «An exclusus amator in a poem attributed to Petronius», Giornale Italiano di Filologia, 21, 1969, pp. 325-327.

SCHWARTZ, L., y ARELlANO, I., 1998: véase Quevedo.

SEGUNDO, Juan, Basia et alia quaedam. Besos y otros poemas, ed. de Olga Gete Carpio (Erasmo), Barcelona, Bosch, 1979.

Soto DE ROJAS, Pedro, Obras, ed. de A. Gallego Morell, Madrid, CSIC, 1950.

SZÖVÉRFFY, J., Secular Latin Lyrics and Minor poetic forms of the Middle Ages, Concord, New Hampshire, Classical Folia Editions, 1992-1995, 4 vols.

Torres Naharro, Bartolomé de, Obra completa, ed. de M. A. Pérez Priego (Biblioteca Castro), Madrid, Turner, 1994.

VegA, Lope de, La Arcadia, ed. de E. S. Morby, Madrid, Castalia, 1975.

- La bella malmaridada o la cortesana, ed. de Ch. Andrés (Clásicos madrileños, 24), Madrid, Castalia, 2001.

- Comedias, I: Los hechos de Garcilaso. El príncipe inocente. El caballero del milagro. El favor agradecido. Laura perseguida. El leal criado. El maestro de danzar. San Segundo. Las justas de Tebas. Los embustes de Fabia (Biblioteca Castro), Madrid, Turner, 1993.

- Comedias, XII: El vaquero de Moraña. La varona castellana. Los amantes sin amor. La gallarda toledana. El Arenal de Sevilla. El cordobés valeroso. La corona merecida. La amistad pagada. Carlos V en Francia. Estefanía la desdichada (Biblioteca Castro $^{72}$ ), Madrid, Turner, 1995.

- Comedias, XIII: La nueva victoria del marqués de Santa Cruz. La prueba de los amigos. El halcón de Federico. La noche toledana. El rústico del cielo. Los españoles en Flandes. La obediencia laureada y primer Carlos de Hungría. El mayordomo de la duquesa de Amalfi. Los guanches de Tenerife y conquista de Canaria. El hombre de bien (Biblioteca Castro), Madrid, Turner, 1997.

-, Comedias, XIV: El secretario de sí mismo. El testigo contra sí. El gran duque de Moscovia. El santo negro Rosambuco. El asalto de Mastrique. La boda entre dos maridos. Don Juan de Castro I. Las mudanzas de fortuna. Los Prados de León. San Isidoro labrador (Biblioteca Castro), Madrid, Turner, 1998.

-, Comedias, XV: El niño inocente de La Guardia. Don Juan de Castro II. El ejemplo de casadas y prueba de la paciencia. El genovés liberal. El hidalgo Bencerraje. El piadoso veneciano. Los Porceles de Murcia. Los Ramírez de Arellano. El anzuelo de Fenisa. La discreta enamorada (Biblioteca Castro), Madrid, 1998.

-, Novelas a Marcia Leonarda, ed. de F. Rico, Madrid, Alianza Editorial, 1968.

-, Obras de Lope de Vega. XI. Comedias de vidas de santos, II. Ed. y estudio de M. Menéndez Pelayo (Biblioteca de Autores Españoles, 186), Reimpr.: La vida de San Pedro Nolasco. San Diego de Alcalá. El niño inocente de la Guardia. Los mártires de Madrid y tres obras más [Juan de Dios y Antón Martín. El saber por no saber, y vida de San Julián de Alcalá de Henares. El rústico del cielo], Madrid, Atlas, 1965.

_, Obras poéticas, ed. de J. M. Blecua, Barcelona, Planeta, 1983.

${ }^{72}$ Todos los vols. citados de esta colección han sido editados por Jesús Gómez y Paloma Cuenca. 
—, El peregrino en su patria, ed. de J. B. Avalle-Arce (Clásicos Castalia, 55), Madrid, 1973.

-, Peribáñez y el Comendador de Ocaña, ed. de D. McGrady (Biblioteca Clásica), Barcelona, Crítica, 1997.

-, Rimas de Tomé de Burguillos, ed. de J. M. Blecua, Barcelona, Planeta, 1976.

-, El villano en su rincón, ed. de J. Mª . Marín, Madrid, Cátedra, 1987.

VILlEGAS, Esteban Manuel, Eróticas o Amatorias, ed. de N. Alonso Cortés (Clásicos Castellanos, 21), Madrid, 1956.

VILLENEUVE (1970): véase Horacio. 


\title{
RESUMEN
}

Cerrásteme la puerta rigurosa: Exclusus amator, un tópico clásico en las letras españolas, por Antonio Ramajo Caño.

El tópico del exclusus amator brota en la Grecia arcaica. Reelaborado una y otra vez en la literatura latina, llegará a la literatura española, en la que aparecerá con cierta frecuencia, al menos hasta entrado el Romanticismo. En el presente trabajo se señalan textos donde el tópico figura, con su permanencia y su variación.

Palabras claves: tradición clásica; tópicos; exclusus amator.

\begin{abstract}
The commonplace of the exclusus amator first arose in ancient Greece. Refashioned again and again in Latin literature, it came into Spanish literature, where it was to appear with a certain frequency until well into Romanticism. The present work points out texts where it appears and shows how it has changed and how it has remained the same.
\end{abstract}

Keywords: Classical tradition; commonplaces; exclusus amator. 